\title{
The Metabolism and Secretion of Aldosterone in Elderly Subjects *
}

\author{
C. Flood, C. Gherondache, G. Pincus, J. F. Tait, † S. A. S. Tait, and \\ S. WiLloughBY \\ (From the Worcester Foundation for Experimental Biology, Shrewsbury, and Cushing \\ Hospital, Framingham, Mass.)
}

\begin{abstract}
Summary. The secretion rates [ $34 \pm 6$ (SE) $\mu \mathrm{g}$ per day, 9 subjects] and metabolic clearance rates (MCR) $[1,288 \pm 120$ (SE) L of plasma per day, 9 subjects] of aldosterone in elderly subjects are significantly lower than those of young subjects $[77 \pm 7$ (SE) $\mu \mathrm{g}$ per day and 1,631 \pm 106 (SE) L per day, respectively]. There is a correlation of the MCR and secretion rate values $(p=0.02)$, but the calculated plasma concentrations (secretion rate/ MCR) are also significantly low in the elderly subjects $[2.6 \pm 0.3$ (SE) compared with concentrations in the plasma from young subjects of $4.7 \pm 0.6$ (SE) $\mu \mathrm{g}$ per $100 \mathrm{ml}$ plasma].

The urinary excretion of radioactivity from oral and intravenously administered labeled aldosterone as aldosterone in the neutral extract, as aldosterone released by acid hydrolysis, and as tetrahydroaldosterone released by incubation with $\beta$-glucuronidase is generally similar for young and elderly subjects except that a larger portion of the oral compared with the intravenous dose is excreted as free aldosterone in the elderly subjects, indicating that the splanchnic extraction is reduced. The calculated splanchnic blood flow (assuming no alteration in extrasplanchnic metabolism) is also slightly lowered.

Therefore, as in patients with mild cardiac dysfunction, the lowered MCR of elderly subjects is due to both reduced splanchnic extraction and blood flow. However, unlike the heart failure patients, in the elderly subjects the plasma concentration of aldosterone is also reduced.
\end{abstract}

\section{Introduction}

Both the rates of metabolism and secretion of certain steroids are lowered in elderly subjects (1-5), but aldosterone has not previously been investigated in this regard.

It is possible that the lowered rate of secretion of certain steroids in elderly subjects is secondary

* Submitted for publication November 2, 1966; accepted March 3, 1967.

Supported by U. S. Public Health Service grants AM-06294 and AM-03179 and Atomic Energy Commission grant AT(30-1)918.

Presented in preliminary form at the International Congress of Gerontology, Vienna, Austria, 1966.

Holder of U. S. Career Award GM-K6-18322.

† Address requests for reprints to Dr. J. F. Tait, Worcester Foundation for Experimental Biology, Shrewsbury, Mass. to the decreased rate of metabolism and the subsequent operation of a feedback system to normalize concentrations of the steroid in blood (6). To examine the hypothesis, the study of the metabolism and secretion of aldosterone has advantages because of the comparative simplicity of its mode of transport and metabolism with weak binding to plasma proteins, nearly complete extraction in one circulation through the liver, and a relatively low rate of extrasplanchnic metabolism $(6,7)$.

\section{Methods}

The nine elderly individuals were male, ranging from 67 to 88 years old, with a mean of 75 . They were selected among a population of 620 geriatric patients of Cushing Hospital, Framingham, Mass. Written consent was given by the patient or a relative or both after 
the nature of the experiment had been explained. The patients were active elderly men admitted only for custodial care; they had no clinical evidence of cardiovascular, renal, or hepatic diseases. The selected individuals were active in the occupational therapy department, with ground privileges, and they walked at least 2 miles a day. Evaluation of their cardiovascular status was done by history and physical examination including fundoscopy, $\mathrm{X}$ ray, electrocardiogram, and occasionally circulation time. Subjects with retinal hemorrhages or exudates, cardiac enlargement, or coronary heart disease were eliminated from the study. Two subjects in this study showing occasionally elevated blood pressure (P.S. and W.H.) were found not to have cardiac enlargement, and their circulation time was below 16 seconds (arm to tongue with Decholin). Renal status was evaluated by urinalysis, blood urea nitrogen, urinary creatinine, and serum and urinary electrolytes. Subjects with proteinuria, red blood cells and casts in the urinary sediment, BUN greater than $25 \mathrm{mg}$ per $100 \mathrm{ml}$, daily urinary excretion of creatinine below $0.50 \mathrm{~g}$, and abnormal values of serum and urinary electrolytes were eliminated from the study. According to our laboratory and data reported by Howell (8), normal BUN levels for subjects in this group with no evidence of cardiovascular, renal, or hepatic disease are 8 to $25 \mathrm{mg}$ per $100 \mathrm{ml}$, and daily urinary creatinine excretions range from 0.50 to $1.80 \mathrm{~g}$. BUN levels in our elderly subjects ranged from 9 to 23 $\mathrm{mg}$ per $100 \mathrm{ml}$, with a mean of $17.5 \mathrm{mg}$. Their mean creatinine excretion was $0.92 \mathrm{~g}$ per 24 hours (range 0.62 to $1.69 \mathrm{~g}$ ). Salt intake was ad libitum. Serum sodium and potassium levels (137 to 143 and 3.7 to $4.8 \mathrm{mEq}$ per $\mathrm{L}$, respectively) in the elderly subjects were all within normal limits for relatively young subjects. The daily urinary sodium and potassium excretion for the elderly subjects was 85 to 167 , with a mean of $119 \mathrm{mEq}$ per 24 hours for sodium, and 44 to 97 , with a mean of $58 \mathrm{mEq}$ per 24 hours for potassium. There are no appropriate published data for electrolytes in serum and urine of normal elderly subjects. The daily urinary output ranged between 360 and $1,800 \mathrm{ml}$ [normal values given by Howell (8) for elderly subjects are 250 to $2,400 \mathrm{ml}$ per 24 hours]. Hepatic status was evaluated by serum alkaline phosphatase levels (Bodansky units) and by the bromosulfophthalein retention test (9) (using $5 \mathrm{mg}$ per $\mathrm{kg}$ body weight, and measuring percentage of dye retention after $15,30,45$, and 60 minutes). All patients presented values in the normal range. Table $I$ shows the clinical data of elderly subjects including their body surface area as calculated from their weight and height (10).

The young subjects were male, 18 to 35 years old, whose clinical and laboratory data were in the normal range. They were members of the staff of the Worcester Foundation and volunteered for the procedure after it had been explained to them. The salt intake of the young individuals was also ad libitum. Urinary excretion of sodium ranged from 126 to 225 , with a mean of $175 \mathrm{mEq}$ per 24 hours and of potassium from 56 to 107, with a mean of $80 \mathrm{mEq}$ per 24 hours. The body surface area of the younger group ranged from 1.85 to 2.12 with a mean of $1.97 \pm 0.04(\mathrm{SE}) \mathrm{m}^{2}$.

The MCR of aldosterone was measured after continuous infusion of $1 \mu \mathrm{c}(0.01 \mu \mathrm{g})$ aldosterone-7- ${ }^{3} \mathrm{H}$ after a priming dose of $1 \mu \mathrm{c}$ (11). The subjects had been in bed at least 10 hours before the infusion was initiated and were supine. In six of the elderly subjects, the MCR was determined in both whole blood and plasma as described elsewhere (11). Some of the data for males have been previously quoted in order to compare the metabolism of aldosterone and 17-isoaldosterone in normal young subjects (12).

The aldosterone secretion rate was studied in the same subjects, usually 1 week later. The subjects were then

TABLE I

Clinical data on the elderly subjects

\begin{tabular}{|c|c|c|c|c|c|c|c|c|c|c|c|c|c|}
\hline Patient & Age & Weight & Height & BSA & $\underset{\text { tocrit }}{\text { Hema- }}$ & BUN* & $\begin{array}{l}\text { Urine } \\
\text { volume }\end{array}$ & $\begin{array}{l}\text { Creat- } \\
\text { inine }\end{array}$ & $\mathrm{Na}$ & $\mathbf{K}$ & $\begin{array}{l}\text { Alkaline } \\
\text { phospha- } \\
\text { tase }\end{array}$ & BSP* & Diagnosis \\
\hline & years & pounds & inches & $m^{2}$ & $\%$ & $100 \mathrm{ml}$ & $24 \mathrm{ml} / \mathrm{hs}$ & $\underset{24 \mathrm{hrs}}{\mathrm{cm} /}$ & \multicolumn{2}{|c|}{$m E q / 24$ hrs } & $\begin{array}{l}\text { Bodan- } \\
\text { sky } U\end{array}$ & $\%$ & \\
\hline P.S. & 72 & 125 & 62 & 1.56 & 42 & 23 & 680 & 0.76 & 124 & 45 & 4 & 2 & $\begin{array}{l}\text { Chronic schizophrenia, } \\
\text { compensated }\end{array}$ \\
\hline W.H. & 72 & 149 & 70 & 1.84 & 39 & 21 & 667 & 0.76 & 152 & 50 & 4 & 2 & $\begin{array}{l}\text { Chronic schizophrenia, } \\
\text { compensated }\end{array}$ \\
\hline W.B. & 71 & 169 & 59.5 & 1.73 & 40 & 21 & 1,385 & 0.93 & 90 & 47 & 4 & 2 & Mental deficiency \\
\hline J.M. & 75 & 157 & 67 & 1.83 & 40 & 9 & 360 & 0.82 & 126 & 97 & 5 & 4 & $\begin{array}{l}\text { Chronic schizophrenia, } \\
\text { compensated }\end{array}$ \\
\hline J.H. & 81 & 121 & 66 & 1.62 & 45 & 14 & 600 & 0.79 & 131 & 80 & 3 & 1 & $\begin{array}{l}\text { Chronic bronchitis; } \\
\text { senile emphysema }\end{array}$ \\
\hline E.D. & 74 & 139 & 71 & 1.80 & 40 & 14 & 1,460 & 1.02 & 86 & 35 & 2 & 1 & Senility, mild \\
\hline J.L. & 88 & 149 & 67 & 1.79 & 40 & 17 & 790 & 0.77 & 85 & 47 & 4 & 2 & Senility, mild \\
\hline W.C. & 67 & 147 & 63.5 & 1.70 & 48 & 23 & 1,795 & 1.60 & 167 & 72 & 5 & 2 & $\begin{array}{l}\text { Chronic schizophrenia, } \\
\text { compensated }\end{array}$ \\
\hline P.Mc. & 77 & 142 & 65 & 1.71 & 48 & 16 & 740 & 0.81 & 106 & 44 & 4 & 2 & Senility, mild \\
\hline
\end{tabular}

* BUN = blood urea nitrogen $; \mathrm{BSP}=$ bromosulfophthalein. 
TABLE II

Data on the metabolism and secretion of aldosterone in elderly and young subjects: comparison with some data from patients with cardiac dysfunction*

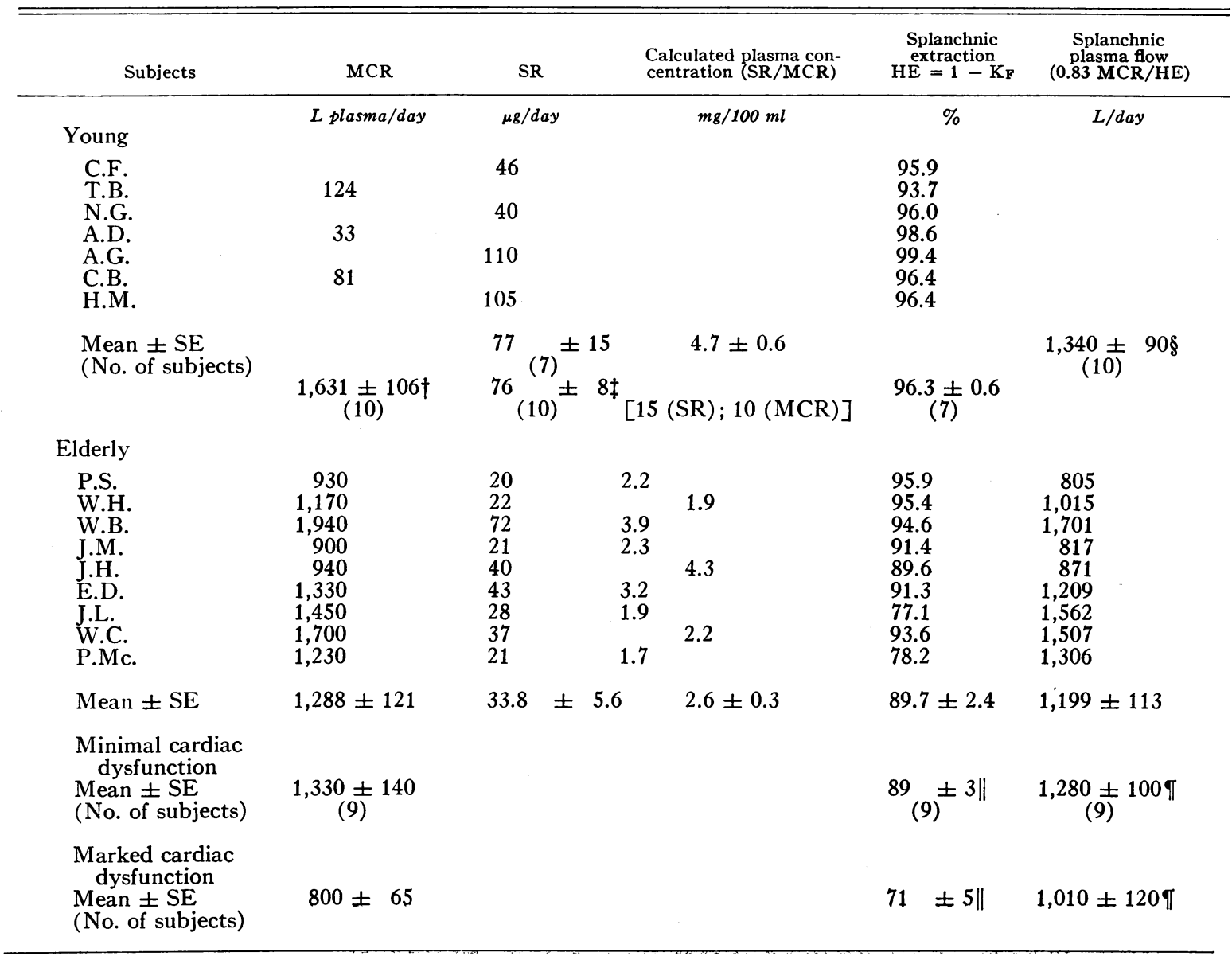

${ }^{*} \mathrm{MCR}=$ metabolic clearance rate; $\mathrm{SR}=$ secretion rate; $\mathrm{HE}=$ hepatic extraction; $\mathrm{K}_{\mathrm{F}}={ }^{14} \mathrm{C} /{ }^{3} \mathrm{H}$ ratio of aldosterone in neutral extract (peak fraction).

$\dagger$ MCR of ten young females (11); Camargo, Dowdy, Hancock, and Luetscher (14) give similar values for young males.

From previous studies of eight other young males.

$0.83 \times \mathrm{MCR} / \mathrm{HE}(7)$.

By hepatic catheterization (7); Camargo and co-workers (14) using a similar method found 97 and $63 \%$ for the hepatic extraction of subjects with mild and marked cardiac dysfunction, respectively.

T 181 I rose bengal method with hepatic catheterization (7).

ambulatory and active before and after the administration of the radioactive material. One $\mu \mathrm{c}, 0.01 \mu \mathrm{g}$ aldosterone-7- ${ }^{8} \mathrm{H}$ was injected intravenously, and $0.35 \mu \mathrm{c}, 2.3$ $\mu \mathrm{g}$ aldosterone-4- ${ }^{14} \mathrm{C}$ was given orally to the same subject simultaneously as previously described (12). Urine was then collected for 48 hours. The methods used to measure the radioactivity as aldosterone in the neutral and acid extracts and tetrahydroaldosterone released by $\beta$-glucuronidase from samples of the 48-hour urinary collection have also been described $(12,13)$. The only difference in the methods of calculation used in this study compared with those of Flood and co-workers (12) was that the ${ }^{14} \mathrm{C} /{ }^{2} \mathrm{H}$ ratio of aldosterone from the neutral ex- tract was taken from the isotopic ratio of the peak fraction after column chromatography of the aldosterone diacetate $^{1}$ (after acetylation) in the present work. In addition, in the studies reported here, the secretion rate of aldosterone was measured by the method of Flood and co-workers (13) from the specific activity of the aldosterone (micrograms in 24 hours/per cent tritiated dose) released from the acid labile conjugate.

1 Due to an isotope fractionation, this could lead to about a $10 \%$ systematic error, but this has a negligible effect on the calculation of hepatic extraction and conclusions from the data. 
TABLE III

Per cent oral ${ }^{14} \mathrm{C}$ - and intravenous ${ }^{3} \mathrm{H}$-aldosterone extracted as aldosterone and tetrahydroaldosterone from 48-hour urine sample

\begin{tabular}{|c|c|c|c|c|c|c|}
\hline \multirow[b]{2}{*}{ Subjects } & \multicolumn{3}{|c|}{${ }^{3} \mathrm{H}(\%$ of dose $)$ as } & \multicolumn{3}{|c|}{${ }^{14} \mathrm{C} /{ }^{3} \mathrm{H}$ (both as fraction of dose) $\%$ as } \\
\hline & $\begin{array}{c}\text { Aldo. in } \\
\text { neutral extract }\end{array}$ & $\begin{array}{l}\text { Aldo. in } \\
\text { acid extract }\end{array}$ & $\begin{array}{l}\text { Tet. aldo. } \\
\text { in enzymic } \\
\text { extract }\end{array}$ & $\begin{array}{c}\text { Aldo.* in } \\
\text { neutral extract }\end{array}$ & $\begin{array}{c}\text { Aldo. in } \\
\text { acid extract }\end{array}$ & $\begin{array}{l}\text { Tet. aldo. } \\
\text { in enzymic } \\
\text { extract }\end{array}$ \\
\hline \multicolumn{7}{|l|}{ Young } \\
\hline $\begin{array}{l}\text { C.F. } \\
\text { T.B. } \\
\text { N.G. } \\
\text { A.D. } \\
\text { A.G. } \\
\text { C.B. } \\
\text { H.M. }\end{array}$ & $\begin{array}{l}0.22 \\
0.20 \\
0.17 \\
0.16 \\
0.10 \\
0.06 \\
0.27\end{array}$ & $\begin{array}{r}6.3 \\
10.1 \\
7.2 \\
5.2 \\
5.4 \\
7.2 \\
8.4\end{array}$ & $\begin{array}{l}58 \\
31 \\
32 \\
\\
\\
39 \\
19\end{array}$ & $\begin{array}{l}4.1 \\
6.3 \\
4.0 \\
1.4 \\
2.6 \\
3.6 \\
3.6\end{array}$ & $\begin{array}{l}68 \\
72 \\
62 \\
83 \\
80 \\
96 \\
61\end{array}$ & $\begin{array}{r}97 \\
129 \\
112 \\
\\
\\
121 \\
126\end{array}$ \\
\hline Mean $\pm \mathrm{SE}$ & $0.17 \pm 0.03$ & $7.1 \pm 0.7$ & $36 \pm 7$ & $3.7 \pm 0.6$ & $75 \pm 5$ & $117 \pm 6$ \\
\hline \multicolumn{7}{|l|}{ Elderly } \\
\hline $\begin{array}{l}\text { P.S. } \\
\text { W.H. } \\
\text { W.B. } \\
\text { J.M. } \\
\text { J.H. } \\
\text { E.D. } \\
\text { J.L. } \\
\text { W.C. } \\
\text { P.Mc. }\end{array}$ & $\begin{array}{l}0.15 \\
0.16 \\
0.19 \\
0.12 \\
0.06 \\
0.13 \\
0.04 \\
0.31 \\
0.05\end{array}$ & $\begin{array}{l}9.2 \\
4.6 \\
6.6 \\
6.3 \\
6.2 \\
8.2 \\
6.5 \\
4.8 \\
6.9\end{array}$ & $\begin{array}{l}40 \\
32 \\
45 \\
42 \\
41 \\
42 \\
24 \\
29 \\
23\end{array}$ & $\begin{array}{r}4.1 \\
4.3 \\
5.4 \\
8.6 \\
10.4 \\
8.7 \\
22.9 \\
6.4 \\
21.8\end{array}$ & $\begin{array}{r}54 \\
78 \\
56 \\
68 \\
79 \\
77 \\
72 \\
75 \\
113\end{array}$ & $\begin{array}{r}111 \\
112 \\
109 \\
107 \\
88 \\
102 \\
116 \\
103 \\
103\end{array}$ \\
\hline Mean $\pm \mathrm{SE}$ & $0.13 \pm 0.03$ & $6.6 \pm 0.5$ & $35 \pm 3$ & $10.3 \pm 2.4$ & $74 \pm 6$ & $106 \pm 3$ \\
\hline
\end{tabular}

* See footnote 1 in text.

In seven of the nine elderly subjects investigated, urine was also collected from 48 to 72 hours to check whether excretion of radioactivity as the acid labile conjugate was complete in 48 hours. This was found to be so $(>95 \%)$ for all subjects studied.

\section{Results}

The mean secretion rates of aldosterone in the elderly and young male subjects were $34 \pm 6$ (SE) $\mu \mathrm{g}$ per day in nine subjects, and $77 \pm 15$ (SE) $\mu \mathrm{g}$ per day in seven subjects, respectively (Table II). The results for the young male subjects are in good agreement with previous studies, $76 \pm 8$ (SE) $\mu \mathrm{g}$ per day, on a similar group of eight volunteers using the same method. The mean secretion rates are significantly lower in the elderly group compared with the mean value of the young group studied in the present series $(p=$ 0.01 ) or the combined mean for all the young males studied by the same method $(p=0.001)$.

The MCR of aldosterone in the elderly group, a mean of $1,288 \pm 121$ (SE) L of plasma per day in nine subjects, are also probably significantly lower $(p=0.04)$ (Table $I)$ than values previously obtained in a young group of subjects, a mean of $1,631 \pm 106(\mathrm{SE}) \mathrm{L}$ per day in ten subjects (11).

In six elderly subjects, the ratio of the MCR of whole blood to the MCR of plasma was $1.27 \pm$ 0.14 (SE). In six normal subjects (including three pregnant women) the corresponding ratio was $1.45 \pm 0.05$. The two mean ratios are not significantly different.

The per cent of the intravenous aldosterone-7${ }^{3} \mathrm{H}$ and oral aldosterone- $4-{ }^{14} \mathrm{C}$ as aldosterone in the acid extract and tetrahydroaldosterone released by $\beta$-glucuronidase in the urine of elderly subjects is similar to that found for young subjects (Table III). The ${ }^{14} \mathrm{C} /{ }^{3} \mathrm{H}$ ratio in the two metabolites (both isotopes expressed as a fraction of the administered dose) is also similar for the two groups of subjects (Table III).

The per cent of the administered aldosterone- ${ }^{3} \mathrm{H}$ excreted as aldosterone in the neutral extract is also similar for elderly and young subjects ( $\mathrm{Ta}$ ble III). However, the ${ }^{14} \mathrm{C} /{ }^{3} \mathrm{H}$ ratio in the urinary free aldosterone is significantly higher $(\mathrm{p}=$ $0.04)$ in the elderly $[10.3 \pm 2.4(\mathrm{SE}) \%]$ compared with the young group [3.7 $\pm 0.6(\mathrm{SE}) \%]$. 


\section{Discussion}

The secretion rate of aldosterone is markedly lowered in elderly subjects. This is not due to a high salt intake, as the dietary intake and urinary excretion of sodium are normal or below normal in all these subjects (Table I). There is no correlation of secretion rate and sodium or potassium excretion (Tables I and II) within the elderly or young group. The excretion of both sodium and potassium is lower in the elderly compared with the young group (mean $\mathrm{Na} 175$ vs. 119 and mean $\mathrm{K} 80$ vs. $58 \mathrm{mEq}$ ), but the sodium/potassium ratios are similar.

As previously described, the elderly subjects chosen were probably as active as most normal young subjects; the older men included a 2-mile walk in their daily regime. They stayed in bed at night for 8 to 10 hours and did not return to bed during the day. Their postural behavior during 24 hours was generally similar to that of most young subjects. It is therefore unlikely that posture or activity could be a major factor in explaining the low aldosterone secretion rates in the elderly subjects.

The mean body surface area of the elderly subjects $\left[1.73 \pm 0.03(\mathrm{SE}) \mathrm{m}^{2}\right]$ was lower than in the young subjects $\left[1.97 \pm 0.04(\mathrm{SE}) \mathrm{m}^{2}\right]$. However, the ratio of body area is only 1.14 , whereas the ratio for the secretion rates is 2.26. Both the $\mathrm{MCR}$ and secretion rate of aldosterone are also lowered in the elderly subjects, and there is some correlation between MCR and secretion rates be-

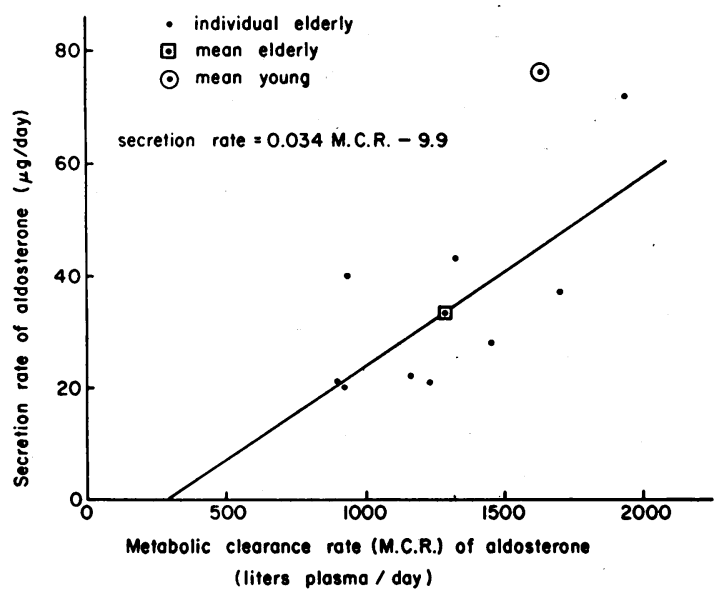

Fig. 1. Secretion and metabolic clearance rates of ELDERLY SUBJECTS. tween the individuals in the group $(\mathrm{r}=0.97, \mathrm{p}=$ 0.02 ) (Figure 1). However, the MCR is not depressed so much as the secretion rate, and the calculated plasma concentration (secretion rate/ $\mathrm{MCR}$ ) is lower in the elderly compared with the young subjects $(p<0.01)$ (Table II). These results indicate that although alterations in metabolism and the subsequent operation of a feedback mechanism may play some role in lowering the secretion rate of aldosterone, it is not the only mechanism causing the effect. However, in the case of cortisol, where the secretion rate is lowered to a smaller extent (2) than for aldosterone, the feedback mechanism may play the dominant role. This remains to be investigated.

The decreased secretion rate could be due to a lowering of excretion of sodium because of reduced renal blood flow (15) (or some other factor not involving aldosterone) as the primary event. However, in normal subjects and patients with congestive heart failure similar alterations in renal hemodynamics are accompanied by normal or increased secretion of aldosterone, which is not always due to the dietary regime (14). It remains to be seen whether the production of the stimulatory substance or the response of the adrenal to the stimulus is reduced in the elderly subjects. As infusion of angiotensin could be inadvisable in such subjects, further investigation must await the development of a simple and reliable method for measurement of angiotensin concentrations in small amounts of blood.

The metabolism of aldosterone may be abnormal due to alterations in splanchnic extraction or blood flow or, less likely, the amount of extrasplanchnic metabolism. The results for the urinary excretion of radioactivity after simultaneous administration of oral aldosterone-4- ${ }^{14} \mathrm{C}$ and intravenous aldosterone- $7-{ }^{3} \mathrm{H}$ indicate that both splanchnic extraction and blood flow may be lowered in the elderly subjects.

The proportion of the oral compared with the intravenous dose excreted as free aldosterone is higher in the elderly than in the young subjects $(p=0.04)$ (Table III). This indicates that the splanchnic extraction is lower in the elderly subjects (12). However, this effect cannot account for the full extent of the lowering of the MCR values (Table III). The proportion of the oral compared with the intravenous dose excreted as the 
aldosterone released from the acid labile conjugate is similar (about $75 \%$ ) for the young and elderly subjects (Table III). As the acid labile conjugate is the major extrahepatic route of metabolism (16, 17 ), this indicates that the amount of such metabolism is not altered appreciably in elderly subjects (12). It therefore appears that some of the lowering of the MCR must be due to decreased hepatic blood flow.

For subjects with minimal and marked cardiac dysfunction (7) the splanchnic plasma flow (HPF) can be calculated knowing the splanchnic extraction $(\mathrm{HE}) . \mathrm{HE}=\left[1-\left({ }^{14} \mathrm{C} /{ }^{3} \mathrm{H}\right.\right.$ in free aldosterone $/{ }^{14} \mathrm{C} /{ }^{3} \mathrm{H}$ in administered steroid) $] \times 100 \%=$ $\left(1-\mathrm{K}_{\mathrm{F}}\right) \times 100 \% \quad(8)$, and $\mathrm{HPF}=(0.83 \times$ MCR)/HE. The calculated values for the elderly subjects using the same formula are shown in Table II. There is a slight decrease in the calculated splanchnic plasma flow in the elderly subjects although it is not significant when compared to corresponding values calculated from the MCR of normal young subjects (11).

These conclusions concerning the extent and the mechanism for the alterations in MCR in elderly subjects are similar to those arrived at for subjects with minimal cardiac dysfunction (7). The calculated values for MCR, splanchnic extraction, and plasma flow ( 7$)$ and the pattern of urinary metabolites, such as the per cent dose excreted as the acid labile conjugate $(14,17)$, are very similar in the two groups of subjects. However, the elderly subjects show a decreased secretion rate and calculated plasma concentration, whereas the patients with mild congestive heart failure show a normal or increased secretion rate and an increased calculated plasma concentration $(14,17)$.

The observation of the markedly decreased secretion rate of aldosterone in elderly subjects emphasizes the need, whatever the mechanism of the effect, for the use of control subjects in the appropriate age group particularly in the studies of the secretion of aldosterone in heart failure and hypertension.

The method for estimating hepatic blood flow from the MCR and hepatic extraction (from the ${ }^{14} \mathrm{C} /{ }^{3} \mathrm{H}$ of the urinary free aldosterone) of aldosterone may have general application. This method assumes a known amount of aldosterone metabolized extrasplanchnically and present in red cells, but this can be verified for a particular group of subjects, and the appropriate correction is small for the subjects so far investigated.

\section{Acknowledgments}

We thank Mr. Chester Blinstrub for technical assistance in determining electrolytes, bromosulfophthalein, and creatinine.

\section{References}

1. Samuels, L. T. Effect of aging on the steroid metabolism as reflected in plasma levels in Hormones and the Aging Process, E. T. Engle and G. Pincus, Eds. New York, Academic Press, 1956, p. 21.

2. Romanoff, L. P., C. W. Morris, P. Welch, R. M. Rodriguez, and G. Pincus. The metabolism of cortisol-4-C $\mathrm{C}^{14}$ in young and elderly men. I. Secretion rate of cortisol and daily excretion of tetrahydrocortisol, allotetrahydrocortisol, tetrahydrocortisone and cortolone $(20 \alpha$ and $20 \beta)$. J. clin. Endocr. 1961, 21, 1413.

3. Romanoff, L. P., C. W. Morris, P. Welch, M. P. Grace, and G. Pincus. Metabolism of progesterone$4-\mathrm{C}^{14}$ in young and elderly men. J. clin. Endocr. 1963, 23, 286.

4. Pincus, G., R. I. Dorfman, L. P. Romanoff, B. L. Rubin, E. Bloch, J. Carlo, and H. Freeman. Steroid metabolism in aging men and women. Recent Progr. Hormone Res. 1955, 11, 307.

5. Pincus, G., L. P. Romanoff, and J. Carlo. The excretion of urinary steroids by men and women of various ages. J. Geront. 1954, 9, 113.

6. Tait, J. F., and S. Burstein. In vivo studies of steroid dynamics in man in The Hormones, G. Pincus, K. Thimann, and E. B. Astwood, Eds. New York, Academic Press, vol. 5, p. 441.

7. Tait, J. F., J. Bougas, B. Little, S. A. S. Tait, and C. Flood. Splanchnic extraction and clearance of aldosterone in subjects with minimal and marked cardiac dysfunction. J. clin. Endocr. 1965, 25, 219.

8. Howell, T. H. A Student's Guide to Geriatrics. Springfield, I1l., Charles C Thomas, 1963, pp. 4344 and 57-58.

9. Annino, J. S. Clinical Chemistry; Principles and Procedures, 2nd ed. Boston, Little, Brown, 1960, p. 205.

10. Documenta Geigy Scientific Tables, 5th ed. Basel, Geigy Pharmaceuticals, 1956, p. 250.

11. Tait, J. F., B. Little, S. A. S. Tait, and C. Flood. The metabolic clearance rate of aldosterone in pregnant and nonpregnant subjects estimated by both single-injection and constant-infusion methods. J. clin. Invest. 1962, 41, 2093.

12. Flood, C., G. Pincus, J. F. Tait, S. A. S. Tait, and S. Willoughby. A comparison of the metabolism of radioactive 17 -isoaldosterone and aldosterone administered intravenously and orally to normal human subjects. J. clin. Invest. 1967, 46, 717. 
13. Flood, C., D. S. Layne, S. Ramcharan, E. Rossipal, J. F. Tait, and S. A. S. Tait. An investigation of the urinary metabolites and secretion rates of aldosterone and cortisol in man and a description of methods for their measurement. Acta endocr. (Kbh.) 1961, 36, 237.

14. Camargo, C. A., A. J. Dowdy, E. W. Hancock, and J. A. Luetscher. Decreased plasma clearance and hepatic extraction of aldosterone in patients with heart failure. J. clin. Invest. 1965, 44, 356.

15. Lindeman, R. D., T. D. Lee, Jr., M. J. Yiengst, and N. W. Shock. Influence of age, renal disease, hypertension, diuretics and calcium on the antidiu- retic responses to suboptimal infusions of vasopressin. J. Lab. clin. Med. 1966, 68, 206.

16. Underwood, R. H., and J. F. Tait. Purification, partial characterization and metabolism of an acid labile conjugate of aldosterone. J. clin. Endocr. 1964, 24, 1110.

17. Cheville, R. A., J. A. Luetscher, E. W. Hancock, A. J. Dowdy, and G. W. Nokes. Distribution, conjugation, and excretion of labeled aldosterone in congestive heart failure and in controls with normal circulation: development and testing of a model with an analog computer. J. clin. Invest. $1966,45,1302$. 